\title{
Ionizability and Bioaccessibility of Externally Added Iron in Legumes and Their Water Soluble Protein Fractions
}

\section{Shirin Adelpilerood \& Jamuna Prakash}

To cite this article: Shirin Adelpilerood \& Jamuna Prakash (2013) lonizability and Bioaccessibility of Externally Added Iron in Legumes and Their Water Soluble Protein Fractions, International Journal of Food Properties, 16:7, 1543-1551, DOI: 10.1080/10942912.2011.600492

To link to this article: https://doi.org/10.1080/10942912.2011.600492

(2) Copyright Taylor and Francis Group, LLC

Accepted author version posted online: 26
Jan 2013. Published online: 24 May 2013.

Submit your article to this journal $\pi$

山ll Article views: 235

Q View related articles $\asymp$

Citing articles: 1 View citing articles 


\title{
IONIZABILITY AND BIOACCESSIBILITY OF EXTERNALLY ADDED IRON IN LEGUMES AND THEIR WATER SOLUBLE PROTEIN FRACTIONS
}

\author{
Shirin Adelpilerood and Jamuna Prakash \\ Department of Food Science and Nutrition, University of Mysore, Manasagangotri, \\ Mysore, India
}

The present investigation focused on determining ionizable iron from legumes, their water soluble protein fraction (albumin), and enzyme hydrolyzed albumin in the presence and absence of external iron. The legumes chosen were decorticated chick pea (Cicer arietinum), green gram (Phaseolus aureus Roxb), lentil (Lens esculenta), and defatted soy (Glycine max merr). Total iron, protein, and ionizable iron were estimated in samples with and without added iron (500 and $1000 \mu \mathrm{g} / \mathrm{g}$ of protein). Protein content of legumes ranged between $22.5-28.5 \mathrm{~g} / 100 \mathrm{~g}$ for all except soy $(59.6 \mathrm{~g} / 100 \mathrm{~g})$; that of albumin fractions and enzyme hydrolyzed albumin was 82.5-89.1 and 82.5-94.1 g/100 g, respectively. Total iron contents were 5.6, 8.13, 6.25, and $15 \mathrm{mg} / 100 \mathrm{~g}$ for chick pea, green gram, lentil, and soy, respectively, whereas ionizable iron ranged between $0.625-0.813 \mu \mathrm{g} / 100 \mathrm{~g}$. On adding external iron, the ionizable iron increased to 719-1445 $\mu \mathrm{g}(500 \mu \mathrm{g} / \mathrm{g}$ protein) and 1219-1545 $\mu \mathrm{g}$ (1000 $\mu \mathrm{g} / \mathrm{g}$ protein). In albumin fraction of legume, the ionizable iron range (as \% of total iron) observed were 28.7-68.0 (500 $\mu \mathrm{g}$ added iron) and 25.0-37.3 (1000 $\mu \mathrm{g}$ added iron). On enzyme hydrolysis of albumin, these ranges were between $256-464 \mu \mathrm{g} / \mathrm{g}$ protein for both levels of added iron. Overall results indicate that ionizable iron from legumes was very low. On adding iron an increase could be seen; however, it was not proportionate to added levels. Better ionizability was observed at a lower level of addition than at higher levels in all samples indicating existence of an optimum level of iron for absorption.

Keywords: Albumin, Lentil, Soy, Chick pea, Green gram.

\section{INTRODUCTION}

Iron deficiency is the most common and widespread nutritional disorder in the world, with a higher incidence observed in the developing countries. The major contributing factors for this are said to be inadequate intake of iron, low bioavailability (1-6\%) of dietary iron from plant foods due to inhibitory factors, ${ }^{[1]}$ low levels of absorption enhancers in the diet, repeated pregnancies in women, increased requirements during growth and development among children and adolescents, parasitic infestations, and chronic blood loss. ${ }^{[2]}$ Legumes and cereals are dietary staples of many populations, especially in developing countries in Asia, and supply the major part of the energy and protein requirements. Because legumes have higher amounts of the essential amino acid lysine and improved

Received 10 May 2010; accepted 2 June 2011.

Address correspondence to Shirin Adelpilerood, Department of Food Science and Nutrition, University of Mysore, Manasagangotri, Mysore 570 006, India. E-mail: shirin59s@yahoo.com 
protein efficiency ratio (PER) compared to wheat ${ }^{[3,4]}$ and other cereals, it is the preferred source of protein among plant source foods.

Iron deficiency is common in these areas even though the dietary iron content may be adequate as all of the ingested iron is not available for absorption. Hence, knowledge of available or ionizable iron from foods or diets can help in improving the iron nutriture of populations. Studies on bioavailability of iron indicate poor absorption from most cereals with the exception of highly refined wheat. ${ }^{[5]}$ Legumes contain more iron than cereals, but its bioavailability in humans has not been examined carefully. Many investigations demonstrate that iron absorption from soybeans and soy protein products is low. ${ }^{[6-11]}$ One of the factors, which appear to play an important role in iron absorption, is the amount and type of protein. ${ }^{[12,13]}$ Since legumes also contain a high quantity of protein, almost 2-3 times that of cereals, it could be one of the factors interfering with iron absorption.

The objective of the study was to determine ionizable iron from legume flours in the presence and absence of added iron. Ionizable iron was also determined in albumin fraction of legumes and partially hydrolyzed albumin fraction from legumes.

\section{MATERIALS AND METHODS}

The chemicals, used for the study, namely, sodium hydroxide, boric acid, sulphuric acid, potassium persulphate, potassium thiocyanate, acetone, ferrous ammonium sulphate, hydrochloric acid, hydroxylamine hydrochloric acid, anhydrous sodium acetate, and acetic acid were of analytical grade and were procured from E-Merck (Mumbai, India) and Qualigens Fine Chemicals (Mumbai, India). The enzymes used for the study were pepsin (Batch No. 3-0060) and pancreatin (Batch No. 0-0864) from Himedia Company (India) and $\alpha, \alpha$ bipyridyl from Sigma Chemical Co. (St. Louis, MO, USA). The iron compound selected for addition was $\mathrm{FeSO}_{4}$ from Sigma Chemical Co. (St. Louis, MO, USA). The food legumes selected were decorticated (without husk) green gram (Phaseolus aureus Roxb), chick pea (Cicer arietinum), lentil (Lens culinaris L.), and defatted soy flour (Glycine max merr), which were purchased from the local market, cleaned free of dirt and foreign material, converted to flour, sieved through a sieve (mesh size $60 \mu$ ), and stored in an airtight container. The study design involved determination of ionizable iron in legume flours and in albumin fractions with or without externally added iron. The levels of iron chosen for addition were $500 \mu \mathrm{g}$ and $1000 \mu \mathrm{g} / \mathrm{g}$ of protein. These were based on the protein iron ratios of recommended dietary allowances for Indians (for example, a typical adult diet will have $60 \mathrm{~g}$ of protein and $30 \mathrm{mg}$ of iron, so based on this, $500 \mu \mathrm{g}$ iron/g protein was taken). The next level selected, $1000 \mu \mathrm{g}$ iron, represented double the ratio to signify extra iron intake as recommended in cases of deficiency or through intake of fortified foods.

\section{Extraction of Albumin Fraction}

Water soluble protein fraction, albumin was extracted from legumes using the following procedure: legume flour was mixed with glass double-distilled water (ratio, 1:10), extracted in a shaker for $60 \mathrm{~min}$ at room temperature, and supernatant separated by centrifugation at $1960 \times \mathrm{g}$ for $20 \mathrm{~min}$. The $\mathrm{pH}$ of the mixture was brought down to 4.0, the isoelectric $\mathrm{pH}$ using $0.1 \mathrm{~N} \mathrm{HCl}$, which precipitated protein, and centrifuged again. The residue was separated and dried in a hot air oven for $24 \mathrm{~h}$ at $40^{\circ} \mathrm{C}$ and stored in an airtight container. $^{[14]}$ 


\section{Partially Enzyme Hydrolyzed Albumin}

The procedure followed for extraction of partially hydrolyzed albumin was as given above except that $0.01 \%$ pancreatin was added to the slurry during the first step of extraction to facilitate hydrolysis of protein.

\section{Analysis}

All analyses were carried out in duplicate samples using two separate replicates, thus representing four recordings. Legume flours, albumin fractions, and enzyme hydrolyzed albumin were analyzed for protein content. The estimation of nitrogen was done by micro Kjeldhal method using a nitrogen distiller. The protein content was determined by multiplying the nitrogen value with $6.25 .{ }^{[15]}$ The sample was charred and incinerated in a muffle furnace at $600^{\circ} \mathrm{C}$ for $6-8 \mathrm{~h}$ and dissolved in glass double-distilled water for preparation of mineral solution. ${ }^{[15]}$ Total iron was estimated in the mineral solution by Wong's method. ${ }^{[16,17]}$ For estimation of in vitro ionizable iron, $4.0 \mathrm{~g}$ of legume flour was extracted in $25 \mathrm{ml}$ pepsin- $\mathrm{HCl}(1 \%$ pepsin in $0.1 \mathrm{~N} \mathrm{HCl})$. The $\mathrm{pH}$ of the mixture was adjusted to $\mathrm{pH}$ 1.35 with $0.1 \mathrm{~N} \mathrm{HCl}$ and incubated at $37^{\circ} \mathrm{C}$ in a metabolic shaker water bath for $90 \mathrm{~min}$. The mixture was centrifuged (models R-24 and R-23, Remi, Bangalore, India) at $705 \times g$ for $45 \mathrm{~min}$. Then $10 \mathrm{ml}$ of protein precipitating solution (10 $\mathrm{g}$ hydroxylamine hydrochloride, $10 \mathrm{~g} \mathrm{TCA}$, and $10 \mathrm{ml}$ of $37 \% \mathrm{HCl}$ made up to $100 \mathrm{ml}$ ) was added to the supernatant and heated in a boiling water bath for $10 \mathrm{~min}$ and centrifuged at $2820 \times g$ for $15 \mathrm{~min}$. The $\mathrm{pH}$ was adjusted to $\mathrm{pH} 7.5$ with $0.1 \mathrm{~N} \mathrm{NaOH}$ and centrifuged at $705 \times g$ for $45 \mathrm{~min}$. The centrifugate was filtered through Whatman No. 44 filter paper and made up to $50 \mathrm{ml} .{ }^{[18]}$ An aliquot of $10 \mathrm{ml}$ extract was taken and $1.0 \mathrm{ml}$ of hydroxylamine hydrochloride solution (10\% hydroxylamine $\mathrm{HCl}$ in water), $5.0 \mathrm{ml}$ of acetate buffer (8.39 $\mathrm{g}$ anhydrous sodium acetate $+12 \mathrm{ml}$ glacial acetic acid made up to $100 \mathrm{ml}$ with water), and $2 \mathrm{ml}$ of $\alpha$ - $\alpha$ bipyridyl $(0.2 \% \alpha-\alpha$-bipyridyl in water) was added and volume was made up to $25 \mathrm{ml}$. The intensity of color was read at $510 \mathrm{~nm}$ in a spectrophotometer (model UV/VIS-108, Systronics Co. Ltd. Ahmadabad, India). The concentration of ionizable iron was read from a standard curve of ferrous ammonium sulfate solution. ${ }^{[19]}$ This method proposed by Rao and Prabhavati ${ }^{[18]}$ is based on the principle that ionizable iron at $\mathrm{pH} 7.5$ is equal to physiologically available iron, and a high correlation was observed between in vitro and in vivo available iron by this method $(r=0.9995)$. The method was further validated by demonstrating an increase in absorbable iron in the presence of meat and ascorbic acid and a decrease in the presence of inhibitory factors like tannin. Based on this correlation, bioaccessible iron was determined in samples by computing the ionizable iron values using a prediction equation $(Y=0.4827+0.4707 X$, where $Y$ is the percent iron absorption in adult men and $X$ is the percent ionizable iron at $\mathrm{pH}$ 7.5). Mean and standard deviation for all data were computed and analysis of variance was used to determine the significant differences in samples, if any, using statistical software SPSS (version 10, SPSS Inc., Chicago, IL, USA).

\section{RESULTS AND DISCUSSION}

The protein and iron content of legume flours and bioaccessible iron are presented in Table 1. The protein content of legume samples varied between 22.50 to $28.56 \mathrm{~g} / 100 \mathrm{~g}$ for chick pea, green gram, and lentil, whereas defatted soy flour had a higher value of 
Table 1 Protein and iron contents of legume flours and bioaccessible iron.

\begin{tabular}{lcccc}
\hline Constituent & Chick pea & Green gram & Lentil & Soy \\
\hline Protein $(\mathrm{g} / 100 \mathrm{~g})$ & $22.50 \pm 0.10$ & $27.50 \pm 0.20$ & $28.56 \pm 0.13$ & $59.69 \pm 0.8$ \\
Total iron $(\mathrm{mg} / 100 \mathrm{~g})$ & $5.60 \pm 0.01$ & $8.13 \pm 0.00$ & $6.25 \pm 0.02$ & $15.00 \pm 0.74$ \\
Ionizable iron $(\mathrm{mg} / 100 \mathrm{~g})$ & $0.687 \pm 0.004$ & $0.813 \pm 0.002$ & $0.813 \pm 0.006$ & $0.625 \pm 0.007$ \\
Bioaccessible iron $(\%)$ & 6.3 & 5.2 & 6.6 & 2.5 \\
Total iron $(\mu \mathrm{g} / \mathrm{g}$ of protein) & 249 & 545 & 219 & 252 \\
Ionizable iron $(\mu \mathrm{g} / \mathrm{g}$ of protein) & $30.53(12.2)$ & $29.54(10.0)$ & $28.44(13.0)$ & $10.47(4.2)$ \\
Added iron-500 $\mu \mathrm{g} / \mathrm{g}$ of protein & & & & $719.1 \pm 3.9$ \\
$\quad$ Total iron $(\mu \mathrm{g} / \mathrm{g}$ of protein) & $749.0 \pm 4.1$ & $796.1 \pm 3.5$ & $751.0 \pm 3.6$ \\
$\quad$ Ionizable iron $(\mu \mathrm{g} / \mathrm{g}$ of protein) & $31.5 \pm 1.1(4.2)$ & $37.5 \pm 1.9(4.7)$ & $156.3 \pm 3.6(21.7)$ & $37.5 \pm 2.7(5.0)$ \\
$\quad$ Bioaccessible iron $(\%)$ & 2.5 & 2.2 & 10.7 & 2.8 \\
Added iron-1000 $\mu \mathrm{g} / \mathrm{g}$ of protein & & & & $1251.2 \pm 3.9$ \\
$\quad$ Total iron $(\mu \mathrm{g} / \mathrm{g}$ of protein) & $1249.1 \pm 2.5$ & $1296.0 \pm 1.7$ & $1219.0 \pm 2.2$ & 2.9 \\
$\quad$ Ionizable iron $(\mu \mathrm{g} / \mathrm{g}$ of protein) & $50.0 \pm 1.4(4.0)$ & $45.0 \pm 1.2(3.5)$ & $272.5 \pm 1.9(22.4)$ & $47.5 \pm 0.9(3.8)$ \\
$\quad$ Bioaccessible iron $(\%)$ & 2.4 & 1.8 & 11.3 & 2.3 \\
\hline
\end{tabular}

Figures in parentheses indicate ionizable iron as $\mathrm{mg} / 100 \mathrm{~g}$ of total iron.

$59.69 \mathrm{~g} / 100 \mathrm{~g}$ of sample. The analyzed values were close to the values reported by Gopalan et al. ${ }^{[20]}$ for Indian foods. Ghavidel and Prakash ${ }^{[21]}$ reported the protein content of whole green gram to be 27.70; whole lentil, 26.50; and whole chick pea, $22.10 \mathrm{~g} / 100 \mathrm{~g}$. Khatoon and Prakash ${ }^{[22]}$ also reported protein content of the above legumes in decorticated form and the values were $24.50,24.40$, and $22.20 \mathrm{~g} / 100 \mathrm{~g}$, respectively. The protein content of full fat soybean is reported to be $43.30 \% ;{ }^{[20]}$ however, in the present study, the protein content was higher because defatted soy flour was used. The iron content of soy flour was highest at $15.00 \mathrm{mg} / 100 \mathrm{~g}$, and the rest of the samples had a lower range of iron. Comparison of the iron content in raw legumes analyzed in the present study with previously published data (converted to units used in this article for ease of comparison) shows that our values are in the range of published iron contents in dehusked chickpea/Bengal gram $(4.60-8.09 \mathrm{mg} / 100 \mathrm{~g}),{ }^{[22-27]}$ lentils $(6.08-12.20 \mathrm{mg} / 100 \mathrm{~g}),{ }^{[24,27-29]}$ and green gram $(5.30-9.05 \mathrm{mg} / 100 \mathrm{~g}) .{ }^{[22,26]}$ For full fat soy flour, the reported values were in the range of $6.64-10.40 \mathrm{mg} / 100 \mathrm{~g} .{ }^{[20,28]}$

The ionizable iron of legumes was found to be very low in all samples ranging from 0.625 to $0.813 \mathrm{mg} / 100 \mathrm{~g}$. Soy had the least ionizable iron of $0.625 \mathrm{mg}$ despite having a higher total iron of $15 \mathrm{mg}$. These results indicate that legumes are only a fair source of available iron. When the ionizable iron was calculated as $\mu \mathrm{g}$ per $\mathrm{g}$ of protein, interestingly the values were very close to each other ranging from 28.44 to $30.53 \mu \mathrm{g} / \mathrm{g}$ of protein for chick pea, green gram, and lentil. In the case of soy, this was found to be very low at only $10.5 \mu \mathrm{g}$ iron/g of protein. When considered as percent bioaccessible iron, the results supported earlier findings. ${ }^{[21,22,26]}$ The bioavailable iron of whole legume as percent of total iron reported by Ghavidel and Prakash ${ }^{[21]}$ was $10.90 \%$ for green gram, $10.20 \%$ for lentil, and $4.68 \%$ for chick pea. Khatoon and Prakash ${ }^{[22]}$ reported that 12.70 and $11.50 \%$ of total iron was bioavailable from green gram and chick pea, respectively. In the present study, around $10-13 \%$ of total iron was bioaccessible in green gram, lentil, and chick pea, whereas in soy only $4.2 \%$ of total iron was bioaccessible. This shows that though soy is a rich source of iron, it is not useful in improving iron nutrition since iron is not absorbed. Schricker et al. ${ }^{[6]}$ reported that iron availability was lower in meals containing soy products in comparison to meals that did not contain soy, and bioaccessible iron decreased further 
with increasing soy protein concentration. They suggested that iron availability from soy could be affected due to the presence of large molecular-weight ( $>6000 \mathrm{kd}$ ) soluble and/or insoluble compounds, possibly protein in nature.

In vivo studies by other scientists have also demonstrated that the bioavailability of non heme iron is appreciably reduced when meat protein in a hamburger meal is replaced by soy flour. ${ }^{[10,30]}$ It was also suggested that the low iron absorption in soy could be because of phytic acid content of soy. ${ }^{[31,32]}$ However, Hurrell et al. ${ }^{[7]}$ removed almost all the phytic acid from soy-protein isolates and observed an increase in iron absorption, but the absorption was only half of what was observed for an egg white control meal, indicating that soy protein itself was inhibitory to iron absorption.

The ionizable iron from legume samples in the presence of added iron was also determined and the results are presented in Table 1. The total iron content of samples ranged from $719.0-796.1 \mu \mathrm{g} / \mathrm{g}$ of protein on addition of $500 \mu \mathrm{g}$ of iron. The ionizable iron per $\mathrm{g}$ of protein was the least in chick pea at $31.5 \mu \mathrm{g}$ followed by green gram and soy, both at $37.50 \mu \mathrm{g}$, and highest for lentil at $156.3 \mu \mathrm{g}$. Among all the legumes, lentil had the highest bioaccessible iron. When compared with availability of intrinsic iron, it can be seen that the percentage of ionizable and bioaccessible iron decreased for chick pea and green gram, but increased slightly for soy and considerably for lentil. These results indicate that in certain legumes, iron added at the level of $500 \mu \mathrm{g} / \mathrm{g}$ of protein did not make any difference, whereas in others the availability increased tremendously. These can be attributed to the compositional differences in individual legume proteins, which influence the bioaccessible iron. The availability of iron from chick pea, green gram, and soy was extremely low. In the case of chick pea and green gram, it was much less than the iron available from flour as such in the absence of external iron. Though there was no change in absolute iron values, the percent digestibility decreased. In soy, the absolute amount and percent digestibility increased slightly, whereas in lentil both absolute amount and percent digestibility enhanced significantly.

When the amount of iron added was $1000 \mu \mathrm{g} / \mathrm{g}$ of protein, there was a concurrent rise in the total iron content of all the samples. The ionizable iron content exhibited an increase in all samples in comparison to the samples with $500 \mu \mathrm{g}$ of added iron. The values were closer to each other $(45-50 \mu \mathrm{g})$ for chick pea, green gram, and soy. For lentil, it was very high at $272.5 \mu \mathrm{g}$. These results also confirm the varying responses of legume protein to added iron. When the bioaccessible iron is considered as percent of total iron in this category, surprisingly the percent availability remains almost similar to samples wherein $500 \mu \mathrm{g}$ of iron was added.

To investigate whether it is predominantly the protein fraction of legumes that influences iron bioaccessibility, the ionizable iron from isolated albumin fractions in the presence of two levels of added iron was determined. The results are presented in Table 2. The water soluble protein fractions that were extracted from legume flours had a very high content of protein ranging from 84.21 to $89.19 \%$. On partial enzyme hydrolysis, the albumin fraction had slightly higher values of protein for chick pea, green gram, and lentil, whereas for soy it was slightly less. This could have been due to partial unfolding of polypeptide chains of protein due to enzyme action, which results in higher extraction of protein in enzyme hydrolyzed samples, though differences were non-significant. The absolute amount of iron ionizable from albumin fraction was quite high in comparison to legume flours as such. Among all samples, soy surprisingly exhibited a high ionizability of iron corresponding to $68 \%$ of total iron. In green gram and lentil, 63.1 and $51.2 \%$ of total iron was ionizable, respectively. This was in contrast to what was seen earlier with flour 
Table 2 Protein contents of albumin fractions and bioaccessible iron.

\begin{tabular}{|c|c|c|c|c|}
\hline Constituent & Chick pea & Green gram & Lentil & Soy \\
\hline \multicolumn{5}{|l|}{ Albumin fraction } \\
\hline Protein $(g / 100 g)$ & $84.94 \pm 2.01$ & $85.91 \pm 1.81$ & $89.19 \pm 1.30$ & $84.21 \pm 1.52$ \\
\hline \multicolumn{5}{|c|}{$500 \mu \mathrm{g}$ added iron/g protein } \\
\hline $\begin{array}{l}\text { Ionizable iron }(\mu \mathrm{g} / \mathrm{g} \\
\text { protein) }\end{array}$ & $128.3 \pm 0.9(25.7)$ & $315.6 \pm 2.1(63.1)$ & $256.0 \pm 2.9(51.2)$ & $340.0 \pm 3.4(68.0)$ \\
\hline Bioaccessible iron (\%) & 14.0 & 30.2 & 24.6 & 32.5 \\
\hline \multicolumn{5}{|c|}{$1000 \mu \mathrm{g}$ added iron $/ \mathrm{g}$ protein } \\
\hline $\begin{array}{l}\text { Ionizable iron }(\mu \mathrm{g} / \mathrm{g} \\
\text { protein })\end{array}$ & $250.7 \pm 1.4(25.1)$ & $373.0 \pm 4.2(37.3)$ & $250.0 \pm 3.9(25.0)$ & $329.0 \pm 2.3(32.0)$ \\
\hline Bioaccessible iron (\%) & 12.3 & 18.0 & 12.3 & 15.5 \\
\hline ' $P$ ' value & \multicolumn{4}{|c|}{$0.162 \mathrm{~ns}$} \\
\hline \multicolumn{5}{|c|}{ Enzyme hydrolyzed albumin fraction } \\
\hline Protein $(\mathrm{g} / 100 \mathrm{~g})$ & $89.6 \pm 1.8$ & $91.5 \pm 1.2$ & $94.1 \pm 0.9$ & $82.5 \pm 1.1$ \\
\hline \multicolumn{5}{|l|}{$500 \mu \mathrm{g}$ added iron $/ \mathrm{g}$ protein } \\
\hline $\begin{array}{l}\text { Ionizable iron }(\mu \mathrm{g} / \mathrm{g} \\
\text { protein })\end{array}$ & $464.4 \pm 3.3(92.9)$ & $457.0 \pm 2.5(91.4)$ & $322.0 \pm 3.9(64.4)$ & $265.0 \pm 3.7(53.0)$ \\
\hline Bioaccessible iron (\%) & 44.2 & 43.3 & 30.6 & 25.4 \\
\hline \multicolumn{5}{|c|}{$1000 \mu \mathrm{g}$ added iron/g protein } \\
\hline $\begin{array}{l}\text { Ionizable iron }(\mu \mathrm{g} / \mathrm{g} \\
\text { protein })\end{array}$ & $445.5 \pm 4.1(44.6)$ & $450.0 \pm 2.9(45.0)$ & $316.8 \pm 2.4(31.7)$ & $255.4 \pm 1.9(25.5)$ \\
\hline Bioaccessible iron $(\%)$ & 21.5 & 21.6 & 15.1 & 12.5 \\
\hline ' $P$ ' value & \multicolumn{4}{|c|}{$0.022^{*} \mathrm{~ns}$} \\
\hline
\end{tabular}

Figures in parentheses indicate ionizable iron as percent of total iron.

Significant differences between ionizable iron contents of legumes with two levels of added iron on application of students ' $\mathrm{T}$ ' test: ${ }^{*} P \leq 0.05 ;{ }^{* *} P \leq 0.01 ;{ }^{* * *} P \leq 0.001$; ns: not significant.

samples. Chick pea was lowest at $128.3 \mu \mathrm{g}$ (25.7\% of total iron). On addition of $1000 \mu \mathrm{g}$ of iron to the albumin fraction, an increase was observed in absolute values in chick pea and green gram, and a slight decrease was observed in lentil and soy. When ionizable iron was considered as percent of total iron, the results varied for each legume; chick pea remained similar but all others decreased considerably. These results indicate that adding extra iron reduced the percentage of iron that could be ionized; hence, the amount of iron actually absorbed remains the same. These observations are of practical significance in foods fortified with iron wherein there is a possibility that iron absorption may reach an optimum level and would not go beyond that even in the presence of extra iron.

It was also observed that the added iron was available to a larger extent from the albumin fraction than from the flours. This could be related to either the compositional structure of protein in native flour or presence of other inhibiting substances in legumes, such as tannins, phytic acid, dietary fiber, and oxalates. It may be also noted that albumin fraction was separated at acidic $\mathrm{pH}$, which is highly conducive to solubilize iron and increase digestibility. For comparison between two levels of iron added to albumin fraction, Student's $t$-test was done and the differences were not significant $(P$ value $=0.162)$.

It was also interesting to investigate whether proteins can inhibit iron absorption only in the native state or can they also have similar action in the denatured peptide forms. So, the albumin fraction was partially hydrolyzed by pancreatin and used for determination of iron availability. On addition of $500 \mu \mathrm{g}$ of iron, more than $90 \%$ was found to be ionizable in chick pea and green gram. In lentil the value decreased to $64.4 \%$ of total iron and in soy 
Table 3 Analysis of variance for bioaccessible iron between two levels of added iron from legume flours and albumin fractions.

\begin{tabular}{lcccc}
\hline Source of variation & Degrees of freedom & Mean sum of squares & $F$ ratio & $P$ value \\
\hline With 500 mg added iron & 2 & & & \\
Between group & 9 & 98,954 & 13.20787 & $0.002102^{* *}$ \\
Within group & & 7492.05 & & \\
With 1000 mg added Fe & 2 & $1,294,585$ & 106.7845 & $0.000^{* * *}$ \\
Between group & 9 & $12,123.35$ & & \\
Within group & & & & \\
\hline
\end{tabular}

${ }^{* *} P \leq 0.01 ;{ }^{* *} P \leq 0.001$.

it was lowest at 53\%. The bioaccessible iron was in the range of $25.4-44.2 \%$ and followed the order chick pea $<$ green gram $<$ lentil $<$ soy.

On addition of $1000 \mu \mathrm{g}$ iron, the values were almost similar to what was observed in the former (500 $\mu \mathrm{g}$ addition). However, when considered as percent of total iron, the absorption was very much lower. From chick pea and green gram, only $45 \%$ of total iron could be absorbed-from lentil it was $31.7 \%$ and from soy $25.5 \%$. The differences between ionizable iron contents of legumes with two levels of added iron were marginally significant $(P$ value $=0.022)$. These results again confirm that the amount of iron available reaches a maximum level beyond which it cannot be increased. Enzyme hydrolysis definitely increases the iron bioavailability confirming the observation that proteins in the native form could have inhibited the native as well as the added form of iron. Analysis of variance (Table 3) between legume flour, albumin fraction, and enzyme hydrolyzed albumin for bioaccessible iron indicated that there was a highly significant difference in bioaccessible iron values of samples with a level of $500 \mu \mathrm{g}$ iron $(P \leq 0.01)$ and $1000 \mu \mathrm{g}$ added iron $(P \leq 0.001)$.

\section{CONCLUSION}

The major observation of the study can be summarized as follows: the iron availability from legumes as determined by the proportion of iron that could be ionized in general was quite low and in particular was very low for soy. The addition of iron at the $500 \mu \mathrm{g}$ level did not improve the availability of iron from chick pea and green gram and a slight increase was observed in soy. Lentil exhibited higher iron bioavailability in the presence of iron. Increasing the amount of iron at the $500 \mathrm{mg}$ level increased the absolute amount, but the percent availability remained the same. Bioaccessible iron from the isolated albumin fraction of legumes was definitely higher but did not show a proportionate increase on addition of external iron. On enzyme hydrolysis, most of the added iron could be absorbed at the $500 \mu \mathrm{g}$ level in chick pea and green gram. However, it was lower for lentil and soy. In enzyme hydrolyzed albumin, there was a significant difference in bioaccessible iron between samples with two levels of added iron. There were significant differences in the extent of bioaccessible iron between two levels of added iron in all samples. It can be concluded that although the absorption of native iron from legumes was low, added iron could enhance the amount of absorbable iron to a certain extent. Lower levels of addition were better for absorption as indicated by existence of an optimum level of bioaccessibility. 


\section{REFERENCES}

1. Rao, N.B.S.; Vijayasarathy, C.; Prabhavathi, T. Iron absorption from habitual diets of Indians studied by the extrinsic tag technique. Indian Journal of Medical Research 1983, 77, 648-657.

2. Sharma, K.K. Improvimg bioavailability of Iron in Indian diets through food-based approaches for the control of iron deficiency anemia. Food Nutrition and Agriculture 2003, 32, 51-61.

3. Fenn, D.; Lukow, O.M.; Humphreys, G.; Fields, P.G.; Boye, J.I. Wheat-legume composite flour quality. International Journal of Food Properties 2010, 13 (2), 381-393.

4. Jisha, S.; Sheriff, J.; Padmaja, G. Nutritional, functional and physical properties of extrudates from blends of cassava flour with cereal and legume flours. International Journal of Food Properties 2010, 13 (5), 1002-1011.

5. International Nutritional Anemia Consultative Group. Iron Absorption from Cereal and Legumes; The Nutrition Foundation: New York, 1982.

6. Schricker, B.R.; Miller, D.D.; Van Campen, D. In vitro estimation of iron availability in meals containing soy products. Journal of Nutrition 1982, 112 (9), 1696-1705.

7. Hurrell, R.F.; Juillerat, M.A.; Reddy, M.B.; Lynch, S.R.; Dassenko, S.A.; Cook, J.D. Soy protein, phytate, and iron absorption in humans. American Journal of Clinical Nutrition 1992, 56 (3), $573-578$.

8. Cook, J.D.; Morck, T.A.; Lynch, S.R. The inhibitory effect of soy products on nonheme iron absorption in man. American Journal of Clinical Nutrition 1981, 34 (12), 2622-2629.

9. FAO/WHO. Human vitamin and mineral requirements. A joint FAO/WHO Expert Consulation. FAO/WHO: Bangkok, Thailand, Rome, 2002.

10. Hallberg, L.; Rossander, L. Effect of soy protein on nonheme iron absorption in man. American Journal of Clinical Nutrition 1982, 36 (3), 514-520.

11. Christian, P.; Seshadri, S. Effect of addition of bovine milk and vegetable milks on thein vitro availability of iron from cereal meals. Plant Food for Human Nutrition 1989, 39 (4), 317-324.

12. Snedeker, S.M.; Greger, J.L. Metabolism of zinc, copper and iron as affected by dietary protein, cysteine and histidine. Journal of Nutrition. 1983, 113 (3), 644-652.

13. Wapnir, R.A. Protein digestion and the absorption of mineral elements. Advance in Experimental Medicin and Biology 1989, 249, 95-115.

14. Lásztity, R. The Chemistry of Cereal Proteins; CRC Inc.: Baca Raton, FL, 2000.

15. Raghuramulu, N.; Madhavan Nair, K.; Kalyanasundram, S. A Manual for Laboratory Techniques; National Institute of Nutrition, Indian Council of Medical Research: Jamia Osmania, India, 2003.

16. Wong, S.Y. Colorimetric determination of iron and haemoglobin in blood. Journal of Biological Chemistry 1928, 77, 409-412.

17. AOAC (Association of Official Analytical Chemists). Official Methods of Analysis, 17th Edition; Association of Official Analytical Chemists: Arlington, VA, 2000.

18. Rao, N.B.S.; Prabhavathi, T. An in vitro method for predicting the bioavailability of iron from foods. American Journal of Clininical Nutrition 1978, 31 (1), 169-175.

19. AOAC (Association of Official Analytical Chemists). Official Methods of Analysis, 10th Edition; Association of Official Analytical Chemists: Arlington, VA, 1965.

20. Gopalan, C.; Rama Sastri, B.V.; Balasubramanian, S.C.; Rao, N.B.S.; Deosthale, Y.G.; Pant, K.C. Nutritive Value of Indian Foods; National Institute of Nutrition, Indian Council of Medical Research, Jamia Osmania, India, 2004.

21. Ghavidel, R.A.; Prakash, J. The impact of germination and dehulling on nutrients, antinutrients, in vitro iron and calcium bioavailability and in vitro starch and protein digestibility of some legume seeds. LWT-Food Science and Technology 2007, 40 (7), 1292-1299.

22. Khatoon, N.; Prakash, J. Nutrient retention in microwave cooked germinated legumes. Food Chemistry 2006, 97 (1), 115-121. 
23. Sebastiá, V.; Barbera, R.; Farré, R.; Lagarda, M.J. Effects of legume processing on calcium, iron and zinc contents and dialysabilities. Journal of Science of Food and Agriculture 2001, 81 (12), $1180-1185$.

24. Lombardi-Boccia, G.; Di Lullo, G.; Carnovale, E. In-vitro iron dialysability from legumes: Influence of phytate and extrusion cooking. Journal of Science of Food and Agriculture 1991, 55 (4), 599-605.

25. Souci, S.W.; Fachman, W.; Kraut, H.; Scherz, H.; Kloos, G.; Senser, F. Food Composition and Nutrition Tables 1986/87; Medpharm GmbH Scientific Publishers: Stuttgart, Germany, 1986.

26. Hemalatha, S.; Platel, K.; Srinivasan, K. Zinc and iron contents and their bioaccessibility in cereals and pulses consumed in India. Food Chemistry 2007, 102 (4), 1328-1336.

27. Viadel, B.; Barberá, R.; Farré, R. Uptake and retention of calcium, iron, and zinc from raw legumes and the effect of cooking on lentils in Caco-2 cells. Nutrition Research 2006, 26 (11), 591-596.

28. Sandberg, A.S. Bioavailabilityof minerals in legumes. British Journal of Nutrition 2002, 88, S281-S285.

29. Elhardallou, S.B.; Walker, A.F. Binding of Ca by three starchy legumes in the presence of Ca alone or with $\mathrm{Fe}, \mathrm{Zn}, \mathrm{Mg}$ and $\mathrm{Cu}$. Food Chemistry 1995, 52 (4), 379-384.

30. Lynch, S.R.; Dassenko, S.A.; Morck, T.A.; Beard, J.L.; Cook, J.D. Soy protein products and heme iron absorption in humans. American Journal of Clinical Nutrition 1985, 41 (1), 13-20.

31. Bothwell, T.H.; Charlton, R.W.; Cook, J.D.; Finch, C.A. Iron Metabolism in Man; Blackwell Scientific Publications: Oxford, 1979.

32. Gillooly, M.; Bothwell, T.H.; Charlton, R.W.; Torrance, J.D.; Bezwoda, W.R.; MacPhail, A.P.; Derman, D.P.; Novelli, L.; Morrall, P.; Mayet, F. Factors affecting the absorption of iron from cereals. British Journal of Nutrition 1984, 51 (01), 37-46. 